\title{
The mouse model is suitable for the study of viral factors governing transmission and pathogenesis of highly pathogenic avian influenza (HPAI) viruses in mammals
}

\author{
Michela Rigoni $^{1 *}$, Anna Toffan ${ }^{1}$, Elisabetta Viale ${ }^{1}$, Marzia Mancin ${ }^{2}$, \\ Filippo Cilloni ${ }^{1}$, Elena Bertoli ${ }^{1}$, Angela Salomoni ${ }^{1}$, Sabrina Marciano ${ }^{1}$, \\ Adelaide Milani ${ }^{1}$, Bianca ZeCChIN $^{1}$, Ilaria CAPUA ${ }^{1}$, Giovanni CATTOLI ${ }^{1}$ \\ ${ }^{1}$ OIE/FAO and National Reference Laboratory for Avian Influenza and Newcastle disease, OIE Collaborating \\ Centre for Diseases at the Animal-Human Interface, Research \& Development Department, Istituto Zooprofilattico \\ Sperimentale delle Venezie, Viale dell'Università 10, 35020 Legnaro, Padova, Italy \\ ${ }^{2}$ Public Health and Risk Analysis Department, Istituto Zooprofilattico Sperimentale delle Venezie, \\ Viale dell'Università 10, 35020, Legnaro, Padova, Italy
}

(Received 4 January 2010; accepted 11 June 2010)

\begin{abstract}
Highly pathogenic avian influenza (HPAI) viruses of the H5 and H7 subtype pose a major public health threat due to their capacity to cross the species barrier and infect mammals, for example dogs, cats and humans. In the present study we tested the capacity of selected H7 and H5 HPAI viruses to infect and to be transmitted from infected BALB/c mice to contact sentinels. Previous experiments have shown that viruses belonging to both $\mathrm{H} 5$ and $\mathrm{H} 7$ subtypes replicate in the respiratory tract and central nervous system of experimentally infected mice. In this study we show that selected H7N1 and H5N1 HPAI viruses can be transmitted from mouse-to-mouse by direct contact, and that in experimentally infected animals they exhibit a different pattern of replication and transmission. Our results can be considered as a starting point for transmission experiments involving other influenza A viruses with $\alpha$ 2-3 receptor affinity in order to better understand the viral factors influencing transmissibility of these viruses in selected mammalian species.
\end{abstract}

highly pathogenic avian influenza virus / mouse / transmission / H7 / H5

\section{INTRODUCTION}

During April 2009, cases of acute respiratory disease in humans, caused by influenza A pandemic H1N1 in Mexico, were reported [9]. Since that, the virus continues to spread and is causing the first influenza pandemic since 1968. The emergence of this novel H1N1 influenza virus highlighted once more the zoonotic potential of influenza A viruses and the contin-

\footnotetext{
*Corresponding author: mrigoni@izsvenezie.it
}

uous threat posed by the circulation of these viruses in the animal reservoir.

Influenza A viruses circulate in wild aquatic birds, their natural reservoir $[8,16,37]$, but they are able also to cross the species barrier and infect a variety of hosts, including humans. Most influenza viruses that infect wild or domestic birds cause no illness and death and are characterized as being low pathogenic avian influenza (LPAI) viruses. However, viruses within the $\mathrm{H} 5$ and $\mathrm{H} 7$ subtypes have the capacity to acquire genetic properties that confer high virulence 
after their introduction from the wild host to the domestic poultry and are therefore characterized as highly pathogenic avian influenza viruses (HPAI).

Recently, some HPAI viruses of $\mathrm{H} 5$ and $\mathrm{H} 7$ subtype, which have caused a high mortality rates in chickens, have also been associated with mild to severe human infections $[2,7]$.

The increase in isolation of the $\mathrm{H} 5$ and $\mathrm{H} 7$ avian influenza viruses from poultry outbreaks and human patients requires a better understanding of the pathobiology of these viruses for the mammalian host. Interestingly, severe natural infections caused by H5N1 HPAI viruses have been reported in non-avian species, such as feline [18, 19, 34], canine [10], mustelids, and lagomorphs [39]. Therefore, molecular events governing transmission of HPAI viruses in non-avian susceptible species should be properly investigated.

In the present study we used BALB/c mice to evaluate the pathogenicity and the transmission potential of HPAI viruses and to investigate the use of this species to study viral factors affecting transmission in non-avian species. The mouse model has been extensively used to identify virulence determinants of influenza viruses as recently reviewed by Barnard et al. [1]. In contrast, the potential use of the mouse as a model for influenza transmission has been neglected. In fact, transmission of mouse-adapted human influenza viruses between mice was described for the first time about 40 years ago [27]. The reason for this is mainly related to the fact that most human influenza viruses require prior adaptation in mice before they will result in a productive infection [12] and this is most likely due to the predominance of $\alpha$ 2-3 versus $\alpha$ 2-6 sialic acid (SA) receptors (the latter receptors preferred by human influenza viruses) present in murine respiratory tissues [15, 23]. Alternative and probably more appropriate animal models, such as the ferret and the guinea pig, have been therefore tested and developed for studying the pathogenicity and transmission of human influenza viruses as recently reviewed by Belser et al. [2]. However, the use of ferret and guinea pig for studying the pathogenicity and transmission in non-avian species susceptible to influenza viruses exhibiting $\alpha$ 2-3 SA receptor binding affinity remains questionable.

BALB/c mice exhibit mainly $\alpha$ 2-3 linked SA receptors $[15,23,30]$, which are receptors preferred by avian, equine and sea mammal influenza viruses. At present, data on the transmissibility of influenza viruses exhibiting preferential binding to these receptors are limited and mainly confined to avian viruses in avian species with the exception of a recent publication [38] describing the transmission of previously mice-adapted $\mathrm{H} 9 \mathrm{~N} 2 \mathrm{AI}$ viruses to contact mice.

More recently, the presence and distribution of human influenza virus receptors ( $\alpha$ 2-6 SA receptors) in mice has also been revisited and preliminary data indicate the presence of both $\alpha$ 2-3 and $\alpha$ 2-6 SA receptors in the respiratory tract of BALB/c mice [24]. Consequently, mice are potentially suitable for studying influenza virus infection, transmission and reassortment in non-avian species.

The mouse is still considered an important in vivo-model, especially because breeding of this species is cheap, there is an extensive knowledge of their immune system and many immunological reagents are available for this species $[3,36]$.

Furthermore, experiments can be applied more easily on a larger number of animals, often a key factor for transmissibility studies and subsequent statistical analysis [36].

In this study we aim at establishing whether $\mathrm{BALB} / \mathrm{c}$ mice are suitable for transmission experiments using influenza viruses exhibiting preferential $\propto$ 2-3 SA receptor binding affinity and capable of causing infection in non-avian species, namely HPAI viruses of the $\mathrm{H} 7 \mathrm{~N} 1$ and H5N1 subtypes.

\section{MATERIALS AND METHODS}

\subsection{Viruses used in this study}

Two HPAI H7N1, namely A/Ostrich/Italy/2332/ $2000(\mathrm{Os} / 2332)$ and A/Ostrich/Italy/984/2000 (Os/ 984), both isolated from ostriches during the Italian epidemic of 1999-2000, and two HPAI H5N1 belonging to clade 2.2 , namely $\mathrm{A} /$ Turkey/Turkey/1/ 2005 (Tk/05) and A/Mallard/Italy/835/2006 (Mal/ 
Table I. Amino acid sequence comparisons of H5N1(A) and H7N1(B) viruses used in this study.

\begin{tabular}{|c|c|c|c|}
\hline Gene & $\begin{array}{c}\text { Amino acid } \\
\text { sequence similarity (\%) }\end{array}$ & $\begin{array}{l}\text { No. of different } \\
\text { amino acids }\end{array}$ & $\begin{array}{l}\text { Differing amino } \\
\text { acid positions }\end{array}$ \\
\hline \multicolumn{4}{|c|}{ (A) $\mathrm{Tk} / 05$ and $\mathrm{Mal} / 835$} \\
\hline PB2 & 99.7 & 2 & 344,627 \\
\hline PB1 & 99.9 & 1 & 213 \\
\hline PB1-F2 & 98.9 & 1 & 23 \\
\hline PA & 99.6 & 3 & $70,184,547$ \\
\hline HA & 99.6 & 2 & 145,325 \\
\hline NP & 99.8 & 1 & 313 \\
\hline NA & 99.1 & 4 & $34,319,320,414$ \\
\hline M1 & 100 & 0 & - \\
\hline M2 & 98.9 & 1 & 10 \\
\hline NS1 & 100 & 0 & \\
\hline NS2 & 99.1 & 1 & 26 \\
\hline \multicolumn{4}{|c|}{ (B) Os/2332 and Os/984 } \\
\hline PB2 & 99.6 & 3 & $286,591,627$ \\
\hline PB1 & 99.6 & 3 & $598,614,742$ \\
\hline PB1-F2 & 100 & 0 & - \\
\hline PA & 100 & 0 & - \\
\hline HA & 99.5 & 3 & $77,252,264$ \\
\hline NP & 99.6 & 2 & 104,450 \\
\hline NA & 100 & 0 & - \\
\hline M1 & 99.2 & 2 & 134,211 \\
\hline M2 & 100 & 0 & - \\
\hline NS1 & 99.6 & 1 & 59 \\
\hline NS2 & 100 & 0 & - \\
\hline
\end{tabular}

835), isolated in 2005 from a turkey and a mallard respectively, were used in the present study. These viruses were chosen according to the presence or absence of the amino acid Lys in position 627PB2, which is known to play an important part in viral replication and pathogenicity in mice $[22,28]$. No other known residues related to pathogenicity in mice were detected from the amino acid sequence comparison (Tab. I). None of the viruses used in this study possesses the amino acid asparagine in position 701 of PB2 $(701 \mathrm{~N})$, which is considered, together with PB2 $627 \mathrm{~K}$, as a determinant for mammalian interhost transmission in mammals [32].

All viruses were propagated in the allantoic cavity of 9-11 day-old embryonated-specific-pathogen-free (SPF) eggs and were titrated to determine the dose required to infect $50 \%$ of eggs $\left(\mathrm{EID}_{50}\right)$.

The 50\% Mouse Infectious Dose $\left(\mathrm{MID}_{50}\right)$ and $50 \%$ Mouse Lethal Dose $\left(\mathrm{LD}_{50}\right)$ were calculated according to Katz et al. [17], and are reported in Table II.

Briefly, 4-6 week-old female BALB/c mice (Charles River Laboratories s.r.l., Calco, Lecco,
Italia) were intranasally infected with $50 \mu \mathrm{L}$ of 10 -fold serial dilutions of infectious virus ( 8 animals per dilution). Three days after infection, 3 mice from each group were sacrificed and lungs were collected. The remaining 5 mice in each group were monitored daily for clinical signs and mortality was recorded up to 15 days post-infection to determine $\mathrm{LD}_{50}$ values (Tab. II).

$\mathrm{MID}_{50}$ and $\mathrm{LD}_{50}$ values were calculated by the Reed and Muench formula [25].

All experiments using live $\mathrm{H} 7 \mathrm{~N} 1$ and $\mathrm{H} 5 \mathrm{~N} 1$ HPAI viruses were performed in separate isolators under bio safety level 3 (BSL3) containment.

\subsection{Nasal shedding experiment}

Twelve female BALB/c mice of 4-6 weeks of age were infected with $10 \mathrm{LD}_{50}$ of each virus to evaluate nasal shedding. On days 3, 5, 7 and 9 post infection (p.i.), 3 mice from each group were sacrificed and nasal washes were performed using $300 \mu \mathrm{L}$ of sterile PBS. Nasal washes were tested by quantitative 
Table II. $\mathrm{EID}_{50}, \mathrm{LD}_{50}$ and $\mathrm{MID}_{50}$ values of $\mathrm{AI}$ viruses used in this study.

\begin{tabular}{lccccc}
\hline Virus & Pathotype & Strain & EID $_{50}{ }^{\mathrm{a}}$ & $\mathrm{LD}_{50}{ }^{\mathrm{b}}$ & $\mathrm{MID}_{50}{ }^{\mathrm{c}}$ \\
\hline H7N1 & HPAI & A/Ostrich/Italy/2332/2000(Os/2332) & $10^{6.24}$ & $10^{2.75}$ & $10^{2}$ \\
H7N1 & HPAI & A/Ostrich/Italy/984/2000(Os/984) & $10^{6.15}$ & $10^{4.75}$ & $10^{3.3}$ \\
H5N1 & HPAI & A/Turkey/Turkey/1/2005(Tk/05) & $10^{7.7}$ & $10^{3.4}$ & $10^{2.2}$ \\
H5N1 & HPAI & A/Mallard//taly/835/2006 (Mal/835) & $10^{6.83}$ & $>10^{6.83}$ & $>10^{6.83}$ \\
\hline
\end{tabular}

${ }^{\mathrm{a}} \mathrm{EID}_{50}$ : mean egg infectious dose.

${ }^{\mathrm{b}} \mathrm{LD}_{50}$ : mean mouse lethal dose.

${ }^{\mathrm{c}} \mathrm{MID}_{50}$ : mean mouse infectious dose.

Real-Time RT-PCR (RRT-PCR) (see details Sect. 2.5.3) to evaluate the amount of virus shed and processed for virus isolation as described in Section 2.5.1.

\subsection{Transmission experiment}

Four to six-week old female BALB/c mice were divided into two different groups of 10 each. Ten mice (group G1) were infected intranasally with $50 \mu \mathrm{L}$ of a suspension containing $10 \mathrm{LD}_{50}$ of each virus. Twentyfour hours p.i. the infected animals were moved into a clean cage. This cage already hosted 10 sentinel mice (group G2). All mice were observed twice a day for clinical signs and were weighed every two days. Ten uninfected animals were used as negative controls and housed in a separate cage.

\subsection{Sampling procedures}

Lung and brain were collected from dead G1 $\mathrm{H} 7 \mathrm{~N} 1$ mice, as no evidence of viral replication has previously been detected in other organs using the same experimental conditions [26]. In both $\mathrm{H} 5 \mathrm{~N} 1$ G1 groups, lung, brain, spleen, kidney, intestinal content were collected. From all dead sentinels (G2) brain, lung, spleen, liver, kidney and intestinal content were collected. In case of no mortality among infected animals and sentinels, two apparently healthy mice were randomly sacrificed. Mice showing severe signs of disease were also sacrificed for ethical reasons. For each infected or sentinel animal euthanized, a negative control mouse was also sacrificed.

\subsection{Laboratory tests}

\subsubsection{Virological assay}

Tissues samples (approximately $0.3 \mathrm{~g}$ ) and nasal washes (approximately $300 \mu \mathrm{L}$ ) were processed by virus isolation (VI). Tissue samples were homogenized in $3 \mathrm{~mL}$ of phosphate-buffered saline (0.05 M, pH 7.0-7.4) with antibiotics (penicillin: $10000 \mathrm{IU} / \mathrm{mL}$, streptomycin: $10 \mathrm{mg} / \mathrm{mL}$, nystatin: $5000 \mathrm{UI} / \mathrm{mL}$, gentamycin sulphate: $250 \mu \mathrm{g} / \mathrm{mL}$ ) and clarified by centrifugation. The undiluted supernatants were inoculated in 9-11 day old embryonated SPF eggs according to EU guidelines [6].

\subsubsection{Serological assay}

Sera were collected from all surviving mice on day 30 post-contact (p.c.).

Serum samples were tested by an anti-nucleoprotein (NP) in-house indirect ELISA, hemagglutination inhibition assay (HI), and Western blotting using standard procedures [11].

\subsubsection{RRT-PCR analysis}

Samples for molecular analysis were homogenized in $0.5 \mathrm{~mL}$ of phosphate-buffered saline; total RNA was extracted with a commercial kit (Rneasy Mini kit, Qiagen, Milano, Italy) and analysed by quantitative RRT-PCR (qRRT-PCR) using PCR reagents (QuantiTect Multiplex RT-PCR kit, Qiagen) in a one-step protocol.

RRT-PCR analysis were performed for all the tissue sample using an influenza virus primer set [31] specific for the $M$ gene $(M+25, M-124$; $300 \mathrm{nM})$ and hydrolysis probe $(\mathrm{M}+64 ; 100 \mathrm{nM})$.

The qRRT-PCR reaction was performed with the following protocol: $20 \mathrm{~min}$ at $50{ }^{\circ} \mathrm{C}$ and $15 \mathrm{~min}$ at $95{ }^{\circ} \mathrm{C}$ followed by 40 cycles at $94{ }^{\circ} \mathrm{C}$ for $45 \mathrm{~s}$ and $60{ }^{\circ} \mathrm{C}$ for $45 \mathrm{~s}$. Target RNA transcripts were obtained in vitro (Mega Short Script 7, high yield transcription kit, Ambion, Monza, Italy), quantified by spectrophotometer and used to develop a standard calibration curve for viral RNA quantification. 
Table III. Clinical signs, lethality and seroconversion of infected (G1) and contact (G2) mice.

\begin{tabular}{lcccccc}
\hline Virus & \multicolumn{2}{c}{ Infected mice $(\mathrm{G} 1)$} & & \multicolumn{3}{c}{ Contact mice $(\mathrm{G} 2)$} \\
\cline { 2 - 3 } \cline { 7 - 7 } & Clinical signs & Lethality & & Clinical signs & Lethality & Seroconversion \\
\hline Os/2332 & Nervous and respiratory & $10 / 10$ & & Nervous and respiratory & $8 / 10$ & No* \\
Os/984 & Nervous and respiratory & $10 / 10$ & & Nervous and respiratory & $5 / 10$ & No \\
Tk/05 & Respiratory & $10 / 10$ & & Mild respiratory & $4 / 10$ & No \\
Mal/835 & - & - & & - & - & No \\
\hline
\end{tabular}

* No: not observed.

\subsubsection{Sequence analysis}

The Open Reading Frames (ORF) of the original strains and of post-infection isolates were fully sequenced essentially as previously described [14]. DNA sequencing was performed using a 3130xl Genetic Analyzer and BigDye Terminator Mix v3.1 (Applied Biosystems, Monza, Italy).

All the sequences of the original strains were deposited in GenBank: Os/2332 (accession numbers from DQ991309 to DQ 991316); Os/984 (accession numbers from DQ991333 to DQ991339 and EF 376184); TK/05 (accession numbers from EF619980.1 to EF619973.1), Mal/835 (accession numbers from CY016802.1 to CY016795.1).

\subsection{Statistical analysis}

A non parametric test was applied for the statistical analysis. The Pearson Chi Square test was used to evaluate whether there was a significant difference between the number of positive animal within the infected G1 groups and the sentinels G2 groups.

Cox's regression analysis was used for the calculation of the hazard ratio (HR) and the Kaplan Mayer model was applied to the survival analysis.

\section{RESULTS}

\subsection{Pathogenicity of $\mathrm{H} 7$ and $\mathrm{H} 5$ viruses in mice}

As described in the previous sections, BALB-c mice of 4-6 weeks of age were divided in 4 groups of 10 each (group G1) and intranasally infected with the following viruses: two Italian H7N1 HPAI $\left(\mathrm{G} 1_{\mathrm{Os} / 2332}\right.$ and $\left.\mathrm{G} 1_{\mathrm{Os} / 984}\right)$ both isolated from an ostrich, and two H5N1 $\left(\mathrm{Gl}_{\mathrm{Tk} / 05}\right.$ and $\left.\mathrm{G} 1_{\mathrm{Mal} / 835}\right)$ both belonging to clade 2.2 .
Mice belonging to $\mathrm{G}_{\mathrm{Os} / 2332}$ and $\mathrm{G} 1_{\mathrm{Os} / 984}$ exhibited nervous and respiratory signs and all died by days 7 and 10 p.i. respectively (Tab. III and Fig. 1A). Viral RNA was detected in the brain and the lung confirming previous observations [26], with viral loads ranging from $10^{8}$ to $10^{9}$ viral copies $/ \mu \mathrm{L}$ and from $10^{7}$ to $10^{9}$ viral copies $/ \mu \mathrm{L}$ for brain and lung, respectively. A mean weight loss of $14.4 \%$ was recorded in $\mathrm{G} 1_{\mathrm{Os} / 2332}$ whereas an average weight loss of $4.7 \%$ was recorded in $\mathrm{Gl}_{\mathrm{Os} / 984}$.

$\mathrm{G1}_{\mathrm{Tk} / 05}$ mice all died by days 7 and 8 p.i. (Tab. III and Fig. 1A). However, apart from a mild respiratory distress syndrome, severe clinical signs or changes in body weight were not evident in this group (Tab. III).

In contrast to what was observed for both G1 H7N1 mice, in $\mathrm{G} 1_{\mathrm{Tk} / 05}$ viral RNA was not only detected in the brain (values ranging from $10^{7}$ to $10^{9}$ viral copies $/ \mu \mathrm{L}$ ) and in the lung (values ranging from $10^{4}$ to $10^{8}$ viral copies/ $\mu \mathrm{L})$, but also in the spleen (6 subjects; values ranging from $10^{5}$ to $10^{6}$ viral copies $\left./ \mu \mathrm{L}\right)$, in the kidney ( 3 subjects; values ranging from $10^{5}$ to $10^{6}$ viral copies $\left./ \mu \mathrm{L}\right)$, in the intestinal content ( 3 subjects; $10^{7}$ viral copies $/ \mu \mathrm{L}$ ), and in the liver ( 5 subjects; values ranging from $10^{4}$ to $10^{6}$ viral copies $\left./ \mu \mathrm{L}\right)$.

None of the $\mathrm{G} 1_{\mathrm{Mal} / 835}$ mice died spontaneously (Tab. III and Fig. 1A). On day 6 p.i., 2 mice in an apparently healthy status were euthanized. Viral RNA was detected in the lung $\left(5.2 \times 10^{4}\right.$ viral copies $\left./ \mu \mathrm{L}\right)$ of one mouse and in the spleen $\left(5.09 \times 10^{4}\right.$ viral copies $\left./ \mu \mathrm{L}\right)$ of the second mouse. On day 9 p.i., 4 mice in an apparently healthy status were euthanized. Viral RNA was detected in the kidney (values ranging from $2.21 \times 10^{4}$ to $2.38 \times 10^{5}$ viral 
(A)

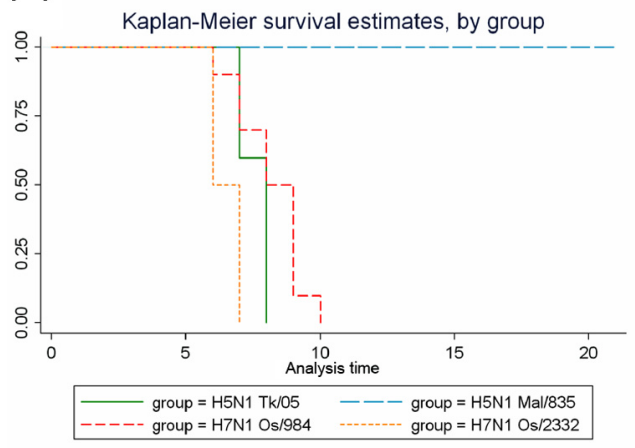

(B)

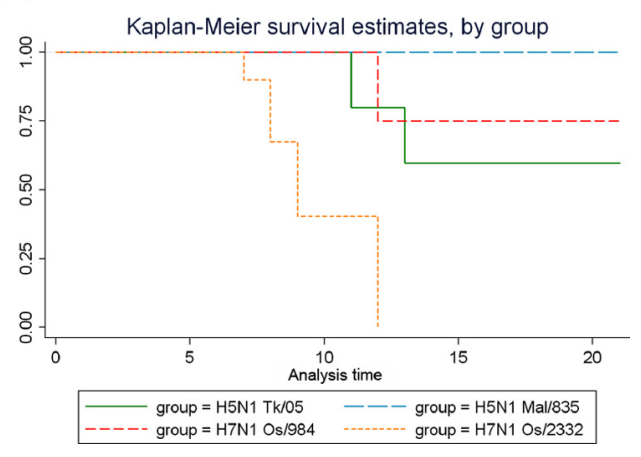

Figure 1. (A) Kaplan-Meier survival curve of infected mice (G1). Ten mice per group were intranasally infected with $10 \mathrm{LD}_{50}$ of each virus. (B) Kaplan-Meyer survival curve of contact mice (G2). Time of death varied from day 7 to 10 p.i. for infected groups (A) and from day 7 to 12 p.c. for contact groups (B). While H5N1 Mal/835 infected and contact mice showed a $100 \%$ survival rate, all the other groups showed mortality rates ranging to $100 \%$ to $75 \%$. (A color version of this figure is available online at www.vetres.org.)

copies $/ \mu \mathrm{L}$ ) and in the brain (values ranging from $4.71 \times 10^{4}$ to $2.09 \times 10^{5}$ viral copies/ $\mu \mathrm{L})$ in the 4 mice. The four surviving mice were euthanized on day 20 p.i. and the samples collected yielded no positive results.

The statistical analysis revealed that the mortality incidence rate was higher in $\mathrm{G} 1_{\mathrm{Os} / 2332}$ mice than in the other G1 groups. Furthermore, the "hazard ratio" estimation revealed that G1 $1_{\mathrm{Os} / 2332}$ mice had 3 fold higher probability (haz. ratio $=3.26$ ) of dying than $\mathrm{Gl}_{\mathrm{Tk} / 05}$ mice (both viruses harbouring a lysine in position 627 of PB2), and that this difference was statistically significant $(p<0.05)$. There was no significant difference between $\mathrm{G}_{\mathrm{Tk} / 05}, \mathrm{G} 1_{\mathrm{Os} / 984}$ and $\mathrm{G} 1_{\mathrm{Mal} / 835}$ mice.

The Pearson Chi Square test showed that the number of positive animals was not significantly different between $\mathrm{G}_{\mathrm{Os} / 2332}$ and $\mathrm{G}_{\mathrm{Os} / 984}$, whereas the number of positive mice was significantly different between $\mathrm{G} 1_{\mathrm{Tk} / 05}$ and $\mathrm{G} 1_{\mathrm{Mal} / 835}$ $(p=0.04)$. In both G1 H7N1 mice, the number of positive animals was not statistically significant when compared to $\mathrm{G}_{\mathrm{Tk} / 05}$, but significantly different when compared to $\mathrm{G} 1_{\mathrm{Mal} / 835}$.

\subsection{Nasal shedding evaluation}

In mice infected with Os/2332, virus shedding had a peak value on day 3 p.i. $(4.1 \times$ $10^{8}$ viral copies $(\mu \mathrm{L})$ and decreased by day 5 $\left(9.9 \times 10^{7}\right.$ viral copies $\left./ \mu \mathrm{L}\right)$. A moderate decrease was then observed by the end of the experiment at day 9 p.i., reaching $3.6 \times 10^{7}$ viral copies/ $\mu \mathrm{L}$ (Fig. 2A).

Mice infected with Os/984 showed high viral titre on day 3 p.i. $\left(2.26 \times 10^{8}\right.$ viral cop$\mathrm{ies} / \mu \mathrm{L})$, a decrease on day $5\left(7 \times 10^{7}\right.$ viral cop$\mathrm{ies} / \mu \mathrm{L})$, an increase on day $7\left(1.5 \times 10^{8}\right.$ viral copies $/ \mu \mathrm{L})$, finally reaching $1.63 \times 10^{7}$ viral copies/ $\mu \mathrm{L}$ by day 9 p.i. (Fig. $2 \mathrm{~A}$ ).

With the $\mathrm{H} 5 \mathrm{~N} 1$ viruses, Tk/05 reached its peak $\left(2 \times 10^{8}\right.$ viral copies $\left./ \mu \mathrm{L}\right)$ on day 7 p.i. and decreased by day 9 p.i. $\left(3.4 \times 10^{7}\right.$ viral copies/ $\mu \mathrm{L}$ ) (Fig. 2B).

Shedding for $\mathrm{Mal} / 835$ peaked at day 3 p.i. $\left(7.6 \times 10^{3}\right.$ viral copies $\left./ \mu \mathrm{L}\right)$ and rapidly decreased. Samples collected on days 5 and 9 yielded negative results for this virus (Fig. 2B).

Viral isolation confirmed the presence of viable virus particles in all the samples tested positive by qRRT-PCR (data not shown).

\subsection{Transmission experiment}

Twenty-four hours after infection, 10 naïve mice per group $\left(\mathrm{G} 2_{\mathrm{Os} / 2332} ; \mathrm{G} 2_{\mathrm{Os} / 984} ; \mathrm{G} 2_{\mathrm{Tk} / 05}\right.$; $\mathrm{G} 2_{\mathrm{Mal} / 835}$ ) were placed in the same cage with inoculated animals.

Among $\mathrm{G} 2 \mathrm{Os}_{\mathrm{O} / 2332}$ mice, 8 out of 10 died (Tabs. IVA and III), and 7 of these were analysed. 

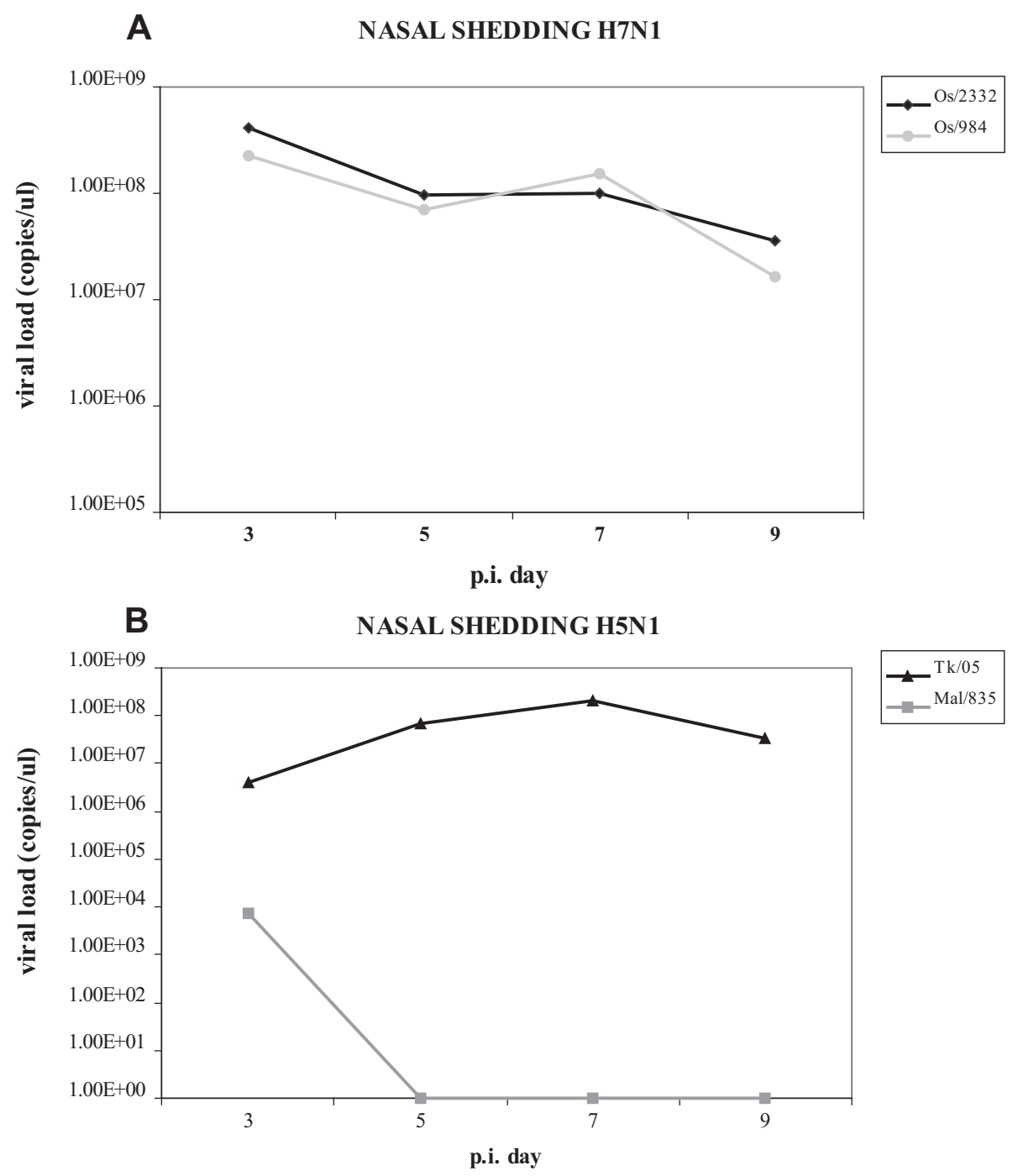

Figure 2. Nasal shedding of infected mice on days 3, 5, 7 and 9 p.i. Twelve female BALB/c mice of 4-6 weeks of age were infected with $10 \mathrm{LD}_{50}$ of each virus to evaluate nasal shedding. On days 3, 5, 7 and 9 p.i., 3 mice from each group were sacrificed and nasal washes were applied. Nasal washes were tested by quantitative Real-Time RT-PCR and viral isolation.

All the samples collected from these mice yielded positive results by qRRT-PCR and 5 out of 7 of these were also confirmed by VI (Tab. IV A).

Among $\mathrm{G} 2_{\mathrm{Os} / 984}$ mice, 2 apparently healthy mice were sacrificed on day 10 p.c., according to the experimental design. The samples collected from only one animal yielded positive results by qRRT-PCR (Tab. IV B). Two contact sentinels were found dead on day 12 p.c., and the organs collected yielded positive results by qRRT-PCR and VI (Tab. IV B). Two other contact sentinels, presenting severe clinical signs, 
Table IV. Quantitative Real-Time RT-PCR and viral isolation of H7N1 contact mice (G2).

\begin{tabular}{|c|c|c|c|c|c|}
\hline ID number & Detail & Organs & qRRT-PCR & Copies $/ \mu \mathrm{L}$ & Virus isolation \\
\hline \multicolumn{6}{|c|}{ (A) $\mathrm{G} 2_{\mathrm{Os} / 2332}$ contact mice } \\
\hline \multirow[t]{2}{*}{1} & Dead (7th p.c.) & Brain & + & $4.34 \mathrm{E}+07$ & + \\
\hline & & Trachea and lung trachea & + & $9.32 \mathrm{E}+05$ & + \\
\hline \multirow[t]{2}{*}{2} & Sacrificed* (7th p.c.) & Brain & - & - & - \\
\hline & & Trachea and lung & - & - & - \\
\hline \multirow[t]{2}{*}{3} & Dead (8th p.c.) & Brain & + & $6.61 \mathrm{E}+08$ & + \\
\hline & & Trachea and lung & + & $1.13 \mathrm{E}+07$ & - \\
\hline \multirow[t]{2}{*}{4} & Sacrificed* (8th p.c.) & Brain & - & - & - \\
\hline & & Trachea and lung & - & - & - \\
\hline \multirow[t]{2}{*}{5} & Dead (8th p.c.) & $N^{a}$ & NA & NA & NA \\
\hline & & NA & NA & NA & NA \\
\hline \multirow[t]{2}{*}{6} & Dead (9th p.c.) & Brain & NA & NA & NA \\
\hline & & Trachea and lung & + & $5.43 \mathrm{E}+07$ & + \\
\hline \multirow[t]{2}{*}{7} & Dead (9th p.c.) & Brain & - & - & - \\
\hline & & Trachea and lung & + & $4.40 \mathrm{E}+07$ & - \\
\hline \multirow[t]{2}{*}{8} & Dead (12th p.c.) & Brain & + & $2.18 \mathrm{E}+09$ & + \\
\hline & & Trachea and lung & + & $1.35 \mathrm{E}+07$ & + \\
\hline \multirow[t]{2}{*}{9} & Dead (12th p.c.) & Brain & + & $7.15 \mathrm{E}+07$ & - \\
\hline & & Trachea and lung & + & $3.65 \mathrm{E}+07$ & - \\
\hline \multirow[t]{2}{*}{10} & Dead (12th p.c.) & Brain & + & $5.05 \mathrm{E}+06$ & - \\
\hline & & Trachea and lung & + & $5.77 \mathrm{E}+07$ & + \\
\hline \multicolumn{6}{|c|}{ (B) $\mathrm{G} 2_{\mathrm{Os} / 984}$ contact mice } \\
\hline \multirow[t]{2}{*}{1} & Sacrificed $^{\mathrm{a}}$ (10th p.c.) & Brain & - & - & - \\
\hline & & Lung/trachea & - & - & - \\
\hline \multirow[t]{2}{*}{2} & Sacrificed $^{\mathrm{a}}$ (10th p.c.) & Brain & + & $7.63 \mathrm{E}+04$ & - \\
\hline & & Lung/trachea & + & $9.54 \mathrm{E}+04$ & - \\
\hline \multirow[t]{2}{*}{3} & Dead (12th p.c.) & Brain & + & $3.90 \mathrm{E}+09$ & + \\
\hline & & Lung/trachea & + & $2.65 \mathrm{E}+07$ & + \\
\hline \multirow[t]{2}{*}{4} & Dead (12th p.c.) & Brain & + & $1.03 \mathrm{E}+10$ & + \\
\hline & & Lung/trachea & + & $1.67 \mathrm{E}+08$ & + \\
\hline \multirow[t]{2}{*}{5} & Sacrificed* (14th p.c.) & Brain & + & $2.62 \mathrm{E}+04$ & - \\
\hline & & Lung/trachea & + & $3.10 \mathrm{E}+04$ & - \\
\hline \multirow[t]{2}{*}{6} & Sacrificed* (14th p.c.) & Brain & + & $3.26 \mathrm{E}+07$ & - \\
\hline & & Lung/trachea & + & $4.49 \mathrm{E}+05$ & - \\
\hline
\end{tabular}

* Mice euthanized for ethical reasons.

${ }^{\text {a }}$ Not analyzed. Samples found putrefied could not be processed.

were sacrificed on day 14 p.c. and samples collected yielded positive results by qRRTPCR only (Tab. IV B).

It is of note that in both $\mathrm{H} 7 \mathrm{~N} 1 \mathrm{G} 2$ groups viral RNA was detected exclusively in the brain and the respiratory tract.

No seroconversion was detected by any of the serological tests used (HI, ELISA and Western blotting) in $\mathrm{G} 2{ }_{\mathrm{Os} / 984}$ and $\mathrm{G} 22_{\mathrm{Os} / 2332}$ surviving mice (Tab. III).
Among $\mathrm{G} 2_{\mathrm{Tk} / 05}$ sentinel mice, 4 out of 10 died, without evident clinical signs or changes in body weight (Tab. III and Fig. 1B), with viral RNA detected in multiple organs (Tab. V A). Two out of six sentinels sacrificed on day 20 p.c. showed viral RNA in the brain and the spleen (Tab. V A).

None of $\mathrm{G} 2{ }_{\mathrm{Mal} / 835}$ mice died spontaneously (Tab. III and Fig. 1B). Viral RNA was detected only in the trachea/lung of a sentinel sacrificed 
Table V. Quantitative Real-Time PCR and viral isolation results of H5N1 contact mice (G2).

\begin{tabular}{|c|c|c|c|c|c|}
\hline ID number & Detail & Organs $^{\mathrm{b}}$ & qRRT-PCR & Copies $/ \mu \mathrm{L}$ & Virus isolation \\
\hline \multicolumn{6}{|c|}{ (A) $\mathrm{G} 2_{\mathrm{Tk} / 05}$ contact mice } \\
\hline \multirow[t]{4}{*}{1} & Dead (10th p.c) & Brain & + & $5.5 \mathrm{E}+09$ & + \\
\hline & & Lung/trachea & + & $3.05 \mathrm{E}+06$ & + \\
\hline & & Spleen & + & $4.3 \mathrm{E}+04$ & - \\
\hline & & Intestinal content & + & $2.7 \mathrm{E}+05$ & - \\
\hline \multirow[t]{2}{*}{2} & Dead (10th p.c.) & Brain & + & $1.9 \mathrm{E}+06$ & + \\
\hline & & Lung/trachea & + & $2.7 \mathrm{E}+05$ & + \\
\hline \multirow[t]{2}{*}{3} & Dead (12th p.c.) & Brain & $\mathrm{NA}^{\mathrm{a}}$ & NA & NA \\
\hline & & Lung/trachea & + & $2.2 \mathrm{E}+05$ & - \\
\hline \multirow[t]{3}{*}{4} & Dead (12th p.c.) & Brain & + & $3.3 \mathrm{E}+08$ & + \\
\hline & & Lung/trachea & + & $6.4 \mathrm{E}+05$ & + \\
\hline & & Spleen & + & $2.2 \mathrm{E}+05$ & - \\
\hline \multirow[t]{2}{*}{5} & Sacrificed* (20th p.c.) & Brain & + & $3.05 \mathrm{E}+04$ & - \\
\hline & & Spleen & + & $5.96 \mathrm{E}+04$ & - \\
\hline 6 & Sacrificed* (20th p.c.) & Brain & + & $4.82 \mathrm{E}+05$ & + \\
\hline \multicolumn{6}{|c|}{ (B) $\mathrm{G} 2_{\mathrm{Ma} / 835}$ contact mice } \\
\hline 1 & Sacrificed $^{* *}$ (10th p.c.) & Lung/trachea & + & $2.68 \mathrm{E}+05$ & + \\
\hline
\end{tabular}

* Mice sacrificed for ethical reason (severe signs of disease).

** Animal sacrificed according to the experimental protocol.

${ }^{a}$ Not analyzed. Samples found putrefied could not be processed.

${ }^{\mathrm{b}}$ From G2 mice brain, lung, spleen, liver, kidney and intestinal content were collected. This table shows the number of mice and the type of tissues found positive when first processed by qRRT-PCR.

on day 10 p.c. (Tab. VB), and was confirmed by virus isolation.

No seroconversion was observed in either $\mathrm{G} 2_{\mathrm{Tk} / 05}$ or $\mathrm{G} 2_{\mathrm{Mal} / 835}$ surviving animals (Tab. III).

The statistical analysis revealed that the incidence rate of mortality was higher in $\mathrm{G} 2 \mathrm{Os}_{\mathrm{O} / 2332}$ mice than in mice of the other G2 groups. Furthermore, the "hazard ratio" estimation revealed that $\mathrm{G} 2 \mathrm{Os}_{\mathrm{O} / 2332}$ mice have almost 7 times more probability of dying than $\mathrm{G} 2 \mathrm{Tk}_{\mathrm{T} / 05}$ mice (both harbouring a lysine in position 627 of PB2), and this difference was statistically significant $(p<0.05)$. There was no significant difference between $\mathrm{G} 2_{\mathrm{Tk} / 05}, \mathrm{G} 2_{\mathrm{Os} / 984}$ and $\mathrm{G} 2_{\mathrm{Mal} / 835}$ mice.

The Pearson Chi Square test showed the number of infected mice was not significantly different between the $\mathrm{G} 22_{\mathrm{Os} / 2332}$ and $\mathrm{G} 2_{\mathrm{Os} / 984}$, whereas the number of infected mice was significantly different within G2 H5N1 groups $(p=0.07)$. Furthermore, the number of infected mice within G2 H7N1 groups was not significantly different when compared to $\mathrm{G} 2 \mathrm{Tk} / 05$ whereas the difference was significant when compare to $\mathrm{G} 2_{\mathrm{Mal} / 835}$.

\subsection{Sequence analysis}

The complete ORF of the original strains and of the post-infection isolates were sequenced. Post-infection viruses were genetically similar when compared to the respective challenge viruses. Only a few silent mutations were observed in isolates recovered p.i.

\section{DISCUSSION}

Although the efficiency of transmission is a key factor in determining the severity of influenza epidemics, viral properties that affect the transmissibility of influenza viruses among 
mammalian species, including humans, remain poorly understood.

Factors affecting pathogenicity and transmission of influenza viruses appear to be polygenic $[13,21]$ and several mammalian models have been used to investigate this topic, particularly for human influenza viruses $[1,32,33]$.

To our knowledge, this is the first report of direct transmission of HPAI viruses in BALB/ c mice.

Our data demonstrate that $\mathrm{H} 7 \mathrm{~N} 1$ and $\mathrm{H} 5 \mathrm{~N} 1$ HPAI viruses can transmit from infected mice to contact sentinels. Mice infected with different avian influenza virus strains exhibited significant differences in the patterns of infection and transmission, indicating that this species could be used to investigate viral factors influencing transmissibility.

In fact, differences in terms of morbidity and transmissibility between $\mathrm{H} 7 \mathrm{~N} 1$ and $\mathrm{H} 5 \mathrm{~N} 1$ viruses emerged from this study. Severe clinical signs and changes in body weight were recorded with $\mathrm{H} 7 \mathrm{~N} 1$ viruses both in infected and contact sentinels, whereas acute mortality with no apparent signs of disease was recorded in $\mathrm{G1}_{\mathrm{Tk} / 05}$ and $\mathrm{G} 2_{\mathrm{Tk} / 05}$. The strain Mal/835 $\left(\mathrm{LD}_{50}>10^{6}\right)$ showed a non-lethal phenotype in infected mice. Although H5N1 Mal/835 viral replication was detected in different organs in one mouse, the infected animal did not succumb to infection. This was observed also in a previous study [29] using an HPAI H5N1 virus isolated from a human case in 2003 $(\mathrm{HK} / 213)$. This virus replicated to high titre in the lungs of inoculated mice as well as extra pulmonary organs without lethal outcome unless administered at high doses. In addition, for $\mathrm{Mal} / 835$ there was no consistent evidence of transmission to contact sentinels and no seroconversion was observed in surviving animals.

Based on virological and serological data, in both $\mathrm{H} 7 \mathrm{~N} 1$ infected and sentinel groups, inapparent infections did not occur. All the infected mice developed severe clinical signs and died or were euthanized for ethical reasons. Few infected or in-contact mice with both H5N1 viruses resulted infected at the time of sampling but remained apparently healthy. In this experiment it was not possible to assess whether these mice would have developed the disease at a later stage. However, the fact that surviving mice at the end of the experiment did not show seroconversion might suggest that undetectable infections, if any, may occur in a small proportion of mice exposed to HPAI H5N1.

H5N1 Tk/05, harbouring PB2 E627K, showed a highly pathogenic phenotype in mice, causing lethal infection and systemic replication in both infected mice and contact sentinels. This is consistent with extra-respiratory apparatus detection of H5N1 HPAI in infected human patients and with a recent study [6] showing that a single amino acid change at position 627 of PB2 gene may be sufficient for strain HK484 H5N1 to overwhelm the host defence mechanisms that otherwise limit infection to the respiratory tract.

However, data from the present study indicate that the role of the two known major mutations in the PB2 gene, i.e. $\mathrm{E}$ to $\mathrm{K}$ mutation in position PB2 627 and $\mathrm{D}$ to $\mathrm{N}$ in PB2 701 [32], in pathogenicity and transmission of avian influenza viruses in mammalian species appears not to be totally defined, supporting the fact that other virus determinants could be involved. Consistently with previous studies [21, 26, 29], viruses harbouring a PB2 E627K (Os/ 2332 and $\mathrm{Tk} / 05$ ) replicated faster and were more aggressive in mice, although significant differences in terms of morbidity and lethality were revealed among viruses possessing this mutation. On the contrary, no differences were revealed between $\mathrm{Tk} / 05$, harbouring the E627K mutation and Os/984, lacking this mutation. Furthermore, differences in terms of lethality and transmissibility were observed between Os/984 and Mal/835, both lacking PB2 E627K and D701N mutations.

Based on the results of our study, it can be suggested that the role of single amino acid change at position 627 of PB2 gene in overwhelming the host defence mechanisms and provoking extra-respiratory infections [6] may be subtype or even strain specific.

The differences observed in the contact groups $(\mathrm{G} 2)$ reflected the differences in morbidity and pathogenicity observed in the infected groups (G1) with few exceptions. The number of mice infected in the G2 groups with different strains was certainly different even if not 
statistically significant for Os/2332, Os/984 and $\mathrm{Tk} / 05$. Mal/835 was poorly transmissible to incontact mice, being detected only in one, apparently healthy animal. The appearance of disease and mortality also varied among the G2 groups, reflecting the variations observed in the infected (G1) groups.

According to previous studies [20, 26, 28], both HPAI H5N1 and $\mathrm{H} 7 \mathrm{~N} 1$ viruses are pneumo- and neuro-pathogenic in mice. Compared to the lungs, significantly higher virus loads were detected in the brain of mice infected with Os/2332, Os/984 and Tk/05 (data not shown). However this difference was not significant in the sentinels, suggesting that the higher concentration of virus in the brain might be dose-dependant.

The data resulting from this experiment may be a good starting point for further studies. Reverse genetic studies could be performed to better understand the molecular determinants of different viral patterns of transmission in mice.

The authors believe that other inbred strains of mice should be used in transmission studies with avian influenza viruses, since inbred mice vary in their reactions to influenza infection, particularly with regard to inflammatory response and disease severity $[4,35]$.

In addition to that, the use of mice could be suggested as a model for pathogenesis and transmission of other influenza viruses like equine, canine and sea mammals strains targeting 2-3 linked SA receptors.

Acknowledgements. This work was partially funded by the Italian Ministry of Health (RC IZSVE 2004) and by the EU project FLUPATH (contract CT 044220).

\section{REFERENCES}

[1] Barnard D.L., Animal models for the study of influenza pathogenesis and therapy, Antiviral Res. (2009) 82:A110-122.

[2] Belser J.A., Bridges C.B., Katz J.M., Tumpey T.M., Past, present, and possible future human infection with influenza virus A subtype H7, Emerg. Infect. Dis. (2009) 15:859-865.

[3] Belser J.A., Szretter K.J., Katz J.M., Tumpey T.M., Use of animal models to understand the pandemic potential of highly pathogenic avian influenza viruses, Adv. Virus Res. (2009) 73:55-97.

[4] Boon A.C., deBeauchamp J., Hollmann A., Luke J., Kotb M., Rowe S., et al., Host genetic variation affects resistance to infection with a highly pathogenic H5N1 influenza A virus in mice, J. Virol. (2009) 83:10417-10426.

[5] European Commission, CE, Commission Decision 437/2006/CE of 4 August 2006 approving a Diagnostic Manual for avian influenza as provided for in Council Directive 2005/94/EC, Official Journal of the European Union, 2006.

[6] Fornek J.L., Gillim-Ross L., Santos C., Carter V., Ward J.M., Cheng L.I., et al., A single amino acid substitution in a polymerase protein of an $\mathrm{H} 5 \mathrm{~N} 1$ influenza virus is associated with systemic infection and impaired T cell activation in mice, J. Virol. (2009) 83:11102-11115.

[7] Fouchier R.A., Schneeberger P.M., Rozendaal F.W., Broekman J.M., Kemink S.A., Munster V., et al., Avian influenza A virus (H7N7) associated with human conjunctivitis and a fatal case of acute respiratory distress syndrome, Proc. Natl. Acad. Sci. USA (2004) 101:1356-1361.

[8] Fouchier R., Kuiken T., Rimmelzwaan G., Osterhaus A., Global task force for influenza, Nature (2005) 435:419-420.

[9] Garten R.J., Davis C.T., Russell C.A., Shu B., Lindstrom S., Balish A., et al., Antigenic and genetic characteristics of swine-origin $2009 \mathrm{~A}(\mathrm{H} 1 \mathrm{~N} 1)$ influenza viruses circulating in humans, Science (2009) 325:197-201.

[10] Harder T.C., Vahlenkamp T.W., Influenza virus infections in dogs and cats, Vet. Immunol. Immunopathol. (2010) 134:54-60.

[11] Harlow E., Lane D., Antibodies: a laboratory manual, Cold Spring Harbor Laboratory, 1988.

[12] Hartley C.A., Reading P.C., Ward A.C., Anders E.M., Changes in the hemagglutinin molecule of influenza type A (H3N2) virus associated with increased virulence for mice, Arch. Virol. (1997) 142:75-88

[13] Hatta M., Kawaoka Y., Molecular determinants associated with high virulence of influenza A virus, Tanpakushitsu Kakusan Koso (2007) 10:1237-1241.

[14] Hoffmann E., Stech J., Guan Y., Webster R.G., Perez D.R., Universal primer set for the full-length amplification of all influenza A viruses, Arch. Virol. (2001) 146:2275-2289.

[15] Ibricevic A., Pekosz A., Walter M.J., Newby C., Battaile J.T., Brown E.G., et al., Influenza virus receptor specificity and cell tropism in mouse and human airway epithelial cells, J. Virol. (2006) 80:7469-7480. 
[16] Kalthoff D., Globig A., Beer M., Highly pathogenic avian influenza as a zoonotic agent, Vet. Microbiol. (2010) 140:237-245.

[17] Katz J.M., Lu X., Tumpey T.M., Smith C.B., Shaw M.W., Subbarao K., Molecular correlates of influenza A H5N1 virus pathogenesis in mice, J. Virol. (2000) 74:10807-10810.

[18] Keawcharoen J., Oraveerakul K., Kuiken T., Fouchier R.A., Amonsin A., Payungporn S., et al., Avian influenza H5N1 in tigers and leopards, Emerg. Infect. Dis. (2004) 10:2189-2191.

[19] Kuiken T., Rimmelzwaan G., van Riel D., van Amerongen G., Baars M., Fouchier R., Osterhaus A., Avian H5N1 influenza in cats, Science (2004) 306:241.

[20] Lipatov A.S., Krauss S., Guan Y., Peiris M., Rehg J.E., Perez D.R., Webster R.G., Neurovirulence in mice of $\mathrm{H} 5 \mathrm{~N} 1$ influenza virus genotypes isolated from Hong Kong poultry in 2001, J. Virol. (2003) 77:3816-3823.

[21] Maines T.R., Lu X.H., Erb S.M., Edwards L., Guarner J., Greer P.W., et al., Avian influenza (H5N1) viruses isolated from humans in Asia in 2004 exhibit increased virulence in mammals, J. Virol. (2005) 79:11788-11800.

[22] Matrosovich M., Stech J., Klenk H.D., Influenza receptors, polymerase and host range, Rev. Sci. Tech. (2009) 28:203-217.

[23] Matrosovich M.N., Matrosovich T.Y., Gray T., Roberts N.A., Klenk H.D., Human and avian influenza viruses target different cell types in cultures of human airway epithelium, Proc. Natl. Acad. Sci. USA (2004) 101:4620-4624.

[24] Ning Z.Y., Luo M.Y., Qi W.B., Yu B., Jiao P.R., Liao M., Detection of expression of influenza virus receptors in tissues of BALB/c mice by histochemistry, Vet. Res. Commun. (2009) 33:895-903.

[25] Reed L.J., Muench H., A simple method of estimating fifty percent endpoints, Am. J. Hyg. (1938) 27:493-497.

[26] Rigoni M., Shinya K., Toffan A., Milani A., Bettini F., Kawaoka Y., et al., Pneumo- and neurotropism of avian origin Italian highly pathogenic avian influenza $\mathrm{H} 7 \mathrm{~N} 1$ isolates in experimentally infected mice, Virology (2007) 364:28-35.

[27] Schulman J.L., The use of an animal model to study transmission of influenza virus infection, Am. J. Public Health Nations Health (1968) 58:2092-2096.

[28] Shinya K., Hamm S., Hatta M., Ito H., Ito T., Kawaoka Y., PB2 amino acid at position 627 affects replicative efficiency, but not cell tropism, of Hong Kong H5N1 influenza A viruses in mice, Virology (2004) 320:258-266.

[29] Shinya K., Hatta M., Yamada S., Takada A., Watanabe S., Halfmann P., et al., Characterization of a human H5N1 influenza A virus isolated in 2003, J. Virol. (2005) 79:9926-9932.

[30] Shinya K., Ebina M., Yamada S., Ono M., Kasai N., Kawaoka Y., Avian flu: influenza virus receptors in the human airway, Nature (2006) 440:435-436.

[31] Spackman E., Senne D.A., Myers T.J., Bulaga L.L., Garber L.P., Perdue M.L., et al., Development of a real-time reverse transcriptase PCR assay for type A influenza virus and the avian $\mathrm{H} 5$ and $\mathrm{H} 7$ hemagglutinin subtypes, J. Clin. Microbiol. (2002) 40:32563260 .

[32] Steel J., Lowen A.C., Mubareka S., Palese P., Transmission of influenza virus in a mammalian host is increased by PB2 amino acids $627 \mathrm{~K}$ or $627 \mathrm{E} /$ 701 N, PLoS Pathog. (2009) 5:e1000252.

[33] Steel J., Staeheli P., Mubareka S., Garcia-Sastre A., Palese P., Lowen A.C., Transmission of pandemic H1N1 influenza virus and impact of prior exposure to seasonal strains or interferon treatment, J. Virol. (2010) 84:21-26.

[34] Thanawongnuwech R., Amonsin A., Tantilertcharoen R., Damrongwatanapokin S., Theamboonlers A., Payungporn S., et al., Probable tiger-to-tiger transmission of avian influenza H5N1, Emerg. Infect. Dis. (2005) 11:699-701.

[35] Trammell R.A., Toth L.A., Genetic susceptibility and resistance to influenza infection and disease in humans and mice, Expert Rev. Mol. Diagn. (2008) 8:515-529.der Laan J.W., Herberts C., LambkinWilliams R., Boyers A., Mann A.J., Oxford J., Animal models in influenza vaccine testing, Expert Rev. Vaccines (2008) 7:783-793.

[37] Webster R.G., Bean W.J., Gorman O.T., Chambers T.M., Kawaoka Y., Evolution and ecology of influenza A viruses, Microbiol. Rev. (1992) 56: 152-179.

[38] Wu R., Sui Z., Liu Z., Liang W., Yang K., Xiong Z., Xu D., Transmission of avian H9N2 influenza viruses in a murine model, Vet. Microbiol. (2010) 142:211-216.

[39] Zhou J., Sun W., Wang J., Guo J., Yin W., Wu N., et al., Characterization of the $\mathrm{H} 5 \mathrm{~N} 1$ highly pathogenic avian influenza virus derived from wild pikas in China, J. Virol. (2009) 83:8957-8964. 